\title{
Institutional Foundations of Ukraine's Transition to the Green Economy
}

\author{
Igor Timoshenkov ${ }^{1}$, Vitalina Babenko ${ }^{2}$, Olga Nashchekina $^{3} \&$ Oksana Makovoz $^{3}$ \\ ${ }^{1}$ International Business and Economic Theory Department, V. N. Karazin Kharkiv National University, Kharkiv, \\ Ukraine \\ ${ }^{2}$ International E-commerce and Hotel \& Restaurant Business Department, V. N. Karazin Kharkiv National University, \\ Kharkiv, Ukraine \\ ${ }^{3}$ Management and Taxation Department, National Technical University «Kharkiv Polytechnic Institute», Kharkiv, \\ Ukraine
}

Correspondence: Vitalina Babenko, International E-commerce and Hotel \& Restaurant Business Department, V. N. Karazin Kharkiv National University, 4 Svobody Sq., Kharkiv 61022, Ukraine. Tel: 380-67-570-3573. E-mail: vitalinababenko@karazin.ua

Received: June 23, 2020

Accepted: July 30, 2020

Online Published: August 14, 2020

doi:10.5430/rwe.v11n4p16

URL: https://doi.org/10.5430/rwe.v11n4p16

\begin{abstract}
Possibilities and impediments to Ukraine transition to the Green Economy have been analyzed. The development and improvement of Ukraine environmental law have been determined as the obligatory condition of this transition. The main objectives of the environmental law improvement have been formulated: improving the quality and effectiveness of economic institutions, regulating social relationships in the sphere of environmental protection and assuring the environmental security of society. Codification of Ukraine environmental legislation and adoption of Ukraine environmental code have been characterized as the main way of achieving these objects.
\end{abstract}

Keywords: green economy, environmental law, environmental legislation, formal and informal institutions of environmental protection, effectiveness of institutions, quality of institutions, environmental code

\section{Introduction}

By the beginning of the XXI century the conceptual statements of the sustainable development theory (Meadows, et al., 1972) had been further developed in the programme documents of the Green Economy (UNDESA, 2012).

The main principles of their realization in Ukraine are reflected in 'Association agreement between the European Union and its Member States, of the one part, and Ukraine, of the other part' (The European Union, 2014). In chapters 4 (Chapter 4 . Sanitary and phytosanitary measures) and 13 (Chapter 13. Trade and sustainable development) of this document Ukraine strategic objectives and tasks in the sphere of environmental protection, trends of improving the environmental activity management, within the general context of integration between Ukraine and the European Union in the fields of policy, trade, culture and strengthening security, have been formulated.

The Agreement provisions corning ecology, as well as the Agreement as a whole, determine the general philosophy of solving these problems. On the one hand, as the key trend of Ukrainian environmental legislation development the Agreement declares its (Ukrainian legislation) harmonization with the European Union legislation. On the other hand, the Agreement records Ukraine right to work out legal forms, adequate for the specific conditions of solving these problems in Ukraine. It is recorded in Article 290. Right to regulate: '1. Recognising the right of the Parties to establish and regulate their own levels of domestic environmental and labour protection and sustainable development policies and priorities, in line with relevant internationally recognised principles and agreements, and to adopt or modify their legislation accordingly, the Parties shall ensure that their legislation provides for high levels of environmental and labour protection and shall strive to continue to improve that legislation. 2. As a way to achieve the objectives referred to in this Article, Ukraine shall approximate its laws, regulations and administrative practice to the EU acquis' (The European Union, 2014).

The actuality and practical importance of solving problems of transition to the Green Economy in Ukraine is, on the one hand, unquestionable. On the other hand, it needs a thorough analysis and an all-round substantiation. It is caused by a fundamental character of goals and objectives of the Green Economy. 
The complication and the high cost of solving the problems of transition to the Green Economy are much greater in the conditions of Ukraine. It happens so because in Ukraine solving all the difficult complex of interconnected production, technical, organizational, financial and economic problems of transition to the Green Economy requires radical changes of the institutional structure of the national economy and the ideology of the state government.

It requires a generalization of the world experience of transition to the Green Economy, considering the prospects and limitations of its usage in Ukraine; formulating the first and foremost tasks, most promising and efficient as to their theoretical importance and practical value in solving the current problems of Ukraine social and economic development.

\section{Materials and Methods}

In solving the problems of transition to the Green Economy two opposite extremes are equally erroneous and faulty: both complete neglecting of the international experience and attempts to copy it mechanically.

Practical application of concrete forms of transition to the Green Economy (for example, mechanisms of financing environmental protection), widespread in other countries of the world, make sense only under the following conditions. First, if they have been previously evaluated as to the pros and cons of their usage in the Ukrainian situation. Second, if the possibility and effectiveness of their adaptation to general cultural, social, economic and institutional conditions of Ukraine have been undoubtedly proved.

Without this attempts at the integration of the national socio-economic system of Ukraine into the international 'green space' are devoid of a systemic foundation, have no economic basis and become no more than a mechanic borrowing of foreign experience in institutional projecting. All this in some cases causes the loss of the imported institutions activity, in other cases brings about their transformation from the factors regulating social relationships in the sphere of environmental protection to factors destructive for the country development.

\section{Results}

Our preliminary notes on analyzing problems of Ukraine transition to the Green Economy made it possible to determine the subject of this publication, its logic and structure.

The subject of the research: economic institutions, regulating social relationships in the sphere of environment end ensuring environmental safety of society in Ukraine. It is the character of these institutions, their structure, trends and dynamics of their development that determine both successes and obstacles on Ukraine way to the Green Economy. First a general characteristic of the institutions will be given. Then peculiarities of environmental legislation of Ukraine, as the most important part of all formal institutions which determine the possibility of Ukraine transition to the Green Economy, will be described. Proceeding from the analysis of environmental legislation of Ukraine the necessity of the legislation codification and introduction of the Environmental Code in the country will be substantiated.

As to the legal force that determines the position and role of normative legal acts in the hierarchy of the field legislation, the following are distinguished:

- The Constitution of Ukraine dated June 28, 1996, No. 254К/96-BP;

- International legal acts, agreements and conventions (The Basel convention on the control of transboundary movements of hazardous wastes and their disposal, United Nations (1989); Convention on environmental impact assessment in a transboundary context, United Nations (1991); Framework Convention on Climate Change, UN FCCC (1992); Convention on biological diversity, United Nations (1992); Kyoto protocol to the United Nations framework convention on climate change, United Nations (1998) etc);

- Laws of Ukraine ('On Environmental Protection' dated June 25, 1991 No. 1264-XII, 'On the Nature Reserve Fund of Ukraine' dated 16 June 1992, No. 2456-XII, 'On protection of the atmospheric air' dated October 16, 1992 No. 2707-XII, 'On the natural reserve fund of Ukraine' dated June 16, 1992 No 2456-XII, 'On the Flora' dated April 9, 1999 No. 591-XIV, 'On the Fauna' dated December 13, 2001 No. 2894-III, 'On the Red Data Book of Ukraine' dated February 7, 2002 No. 3055-III, 'On Plant Quarantine' dated April 3, 2003 No. 3348-XII, 'On the Environmental Network of Ukraine' dated June 24, 2004 No. 1864-IV, 'On Ecological Audit' dated June 24, 2004 No. 1862-IV, 'On the Basic Principles (Strategy) of the State Environmental Policy of Ukraine for the Period until 2020' dated December 21, 2010 No. 2818-VI, 'On Fishery, Industrial Fishery and Protection of Water Bioresources' dated July 8, 2011 No. 3677-VI, 'On Scientific and Scientific and Technical Activity' dated November 26, 2015 No. 848-VIII; 'On environmental impact assessment' dated May 23, 2017 No. 2059-VIII etc), and Codes ('Forest Code of Ukraine' dated January 21, 1994 No. 3852-XII, 'Water Code of Ukraine' dated June 6, 1995 No. 213/95-VR, 'Land Code of 
Ukraine' dated January 11, 2005 No. 2768-III);

- Subordinate normative acts of the executive power organs: Decrees of the President of Ukraine ('On the Strategy for Sustainable Development 'Ukraine - 2020' dated January 12, 2015 No. 5/2015; 'On additional measures for the development of forestry, rational use of nature and preservation of objects of the nature reserve fund' dated November 21, 2017 No. 381/2017 etc); Resolutions of the Cabinet of Ministers of Ukraine ('On Approval of the Regulation on the Supervisory Board of the Government Entity «Energy Efficiency Fund»' dated February 28, 2018, No. 142; 'On Approval of the Decommissioning of Main Pipelines of Oil, Gas and their Refining Products»' dated March 28, 2018, No. 209; 'On Approval of the Procedure for the Professional Certification of Persons Intending to Provide Energy Performance Certification and Utility Networks Inspection»' dated July 26, 2018, No. 605; 'On Approval of the Procedure for the State Water Monitoring Implementation»' dated September 19, 2018, No. 758 etc);

- Internal departmental normative acts: Orders of Ministry of environment and natural resources of Ukraine ('On approval of the methodological recommendations for strategic environmental assessment of the state planning documents' dated August 10, 2018, No. 296 etc); Orders of Ministry of regional development, construction, housing and utilities of Ukraine ('On approval of the maintenance of databases of utility system inspection reports, certified energy auditors and specialists in the examination of utility systems, energy certificates' dated March 21, 2018, No. 62; 'On approval of the mandatory list of works (services) included in the expenses for the maintenance of a multi-apartment house and adjacent territory' dated July 27, 2018, No. 190 etc); Orders of Ministry of energy and coal industry of Ukraine ('On approval of the electricity security of supply rules' dated August 27, 2018, No. 448; 'On approval of the procedure of forming the forecasted electricity balance of the unified energy system of Ukraine for the estimated year' dated October 26, 2018, No. 539 etc); Orders of other ministries and departments (Order of the State Statistics Service of 'On approval of templates for state statistical surveillance over prices of natural gas and electricity supplied to consumers' dated July 27, 2018, No. 161 etc);

- Local normative acts (Job description of the environmental engineer (ecologist) of State Enterprise Kharkiv instrument-making plant named after T. G. Shevchenko etc).

A. Hetman, one of the leading Ukrainian specialists in the field of environmental law, stresses: 'Environmental legislation belongs to the newest and complicated branches of Ukrainian legislative system. So, there arises the necessity of working out a Conception of developing the environmental law and legislation of Ukraine. The objective of such Conception must be substantiation of the systemic basis and principles of construction, realization and development of the legislation, ... working out well grounded suggestions as to the types of laws; laws and subordinate regulations; laws and international legal acts; ... a clear definition of legislation regulation criteria; working out recommendations as to optimizing the process of preparing, passing and realizing laws' (Hetman, A., 2014, pp.465-466).

How successfully have these problems solved and can we assert that Ukraine environmental legislation is adequate for the principles and trends of transition to the Green Economy?

The Constitution of Ukraine; Laws of Ukraine: 'On Environmental Protection', 'On protection of the atmospheric air', 'On the Flora', 'On the Fauna', passed during the years of Ukraine being an independent state, have created the necessary favourable foundation for the development of a system of environmental protection and ensuring the environmental safety of society in Ukraine. These acts have formed the legal foundations of reconstruction and renovation of relationships in the sphere of environmental activity, as well as have fulfilled an important social function of environmental preservation and protection during the period of transformational crisis of the society.

Nevertheless they have not made it possible as yet to formulate a completely streamlined and well balanced environmental legislation that would secure a consistent and systematic controlling of relationships in the sphere of environmental protection (Babenko et al., 2019, 2020). It is also necessary to stress the fact that the opinions of Ukrainian scientists and practical specialists concerning the legislative basis of environmental activity, its trends, the tasks of improvement, readiness for solving problems of transition to the Green Economy are essentially different.

So, M. Zanizdra referring to foreign scientists' works considers that 'at this stage of research one can verify, that the conception of Green Industry is one of those economy conceptions that have been examined thoroughly and in detail' (Zanizdra, 2018, p.61), thus Ukraine transition to the Green Economy does not require any additional substantiation.

According to K. Ryabetz, present legislation as a whole is adequate for solving problems of increasing effectiveness of environmental activity, and the main thing now is advancement of public environmental legal awareness (Ryabetz, 2009).

In contradistinction to this, other authors assert, that Ukrainian legislation needs essential improvement, including 
revision of the main laws, regulating environmental activity in Ukraine (Hetman, 2014).

Almost the only characteristic and evaluation of environmental legislation, out of the whole lot of them, that is not disputed, but recognized by all specialists, in the complexity of its structure, which is caused: first, by the character itself of the environmental legislation as a complex field; second, by a multi-level character of the model of the environmental activity state management (Vasylieva, 2018).

One of the reason of this complexity is the fact, that the number of acts, different as to their character, content and function, meant to regulate legal relationships in the ecological sphere at the national level, as shown by the results of legal sources content analysis, amounts more than 400 (to say nothing of the number of local normative acts in concrete territorial units, enterprises and organizations of various branches of national economy).

The natural results of the environmental legislation structural complexity is a great number of approaches and attitudes in choosing the criteria of its differentiation. Without claiming a complete inventory of all available approaches to the legislation differentiation, we shall dwell upon those that are of special interest from the point of view of our research problems.

The results of analyzing the environmental legislation of Ukraine show that in its present state it is ineffective, and the principles of state environmental policy, formulated in the laws, are hardly realized practically (Koniaieva et al., 2019).

Moreover, in a number of situations it happens so that norms of environmental legislation secured by the law have transformed from stimuli of increasing the effectiveness of environmental activity into their opposition. That is, they have become destimuli which make the economic system participants break the legislation, rather than observe it. It happens so, for instance, when it is less costly for businessmen to pay fines for breaking the environmental laws than to invest in eco-friendly technologies.

Of legislative technique peculiarities, that produce a serious negative influence upon the environmental legislation state, a special attention is to be paid to the following:

- lack of balance of many aspects of the relationship system in the sphere of ecology and numerous gaps in the environmental legislation;

- disagreement of the norms stated in the Constitution and the laws and norms in numerous subordinate acts (which often substitute the effect of the laws);

- a great number of reference norms in the legislation, which make it difficult to understand and practically fulfil for the addressees (those who have to observe the laws);

- frequent changes in the legislation, especially in subordinate and interdepartmental normative acts, bringing about for the addressees unjustified high costs of monitoring the environmental legislation.

As it has been quite rightly observed by V. Andreitsev, in order to work out the necessary methodological approaches, doctrines and conceptions of an effective convergence of the environmental legislation of Ukraine and the European Union, first of all it is necessary to reconsider the foundations of the legal environmental regulation in Ukraine (Andreitsev, 2016).

Summing up the abovementioned evaluations and suggestions gives grounds for the conclusion, that overcoming these negative tendencies and supplying the environmental legislation the role of positive stimuli for increasing the effectiveness of environmental protection and environmental activity naturally put forward the task of systematizing the environmental legislation as a strategic trend of improving the whole system of environmental law in Ukraine.

The theory of state and law distinguishes a few forms of systematization of normative legal acts All these forms are meant to improve legislation and bring about a certain normative legal its coordination (Bikadorov, 2008, p.194), though the still have principal differences.

Stock-taking of normative legal material means collection, preservation and keeping normative acts under control, while also creating a search system which will ensure looking for and finding, within the whole lot of acts registered, the necessary information (for instance, the data base 'Legislation of Ukraine'(Legislation of Ukraine, 2019) and others).

The content of the incorporation is the collection of normative acts without changing their subject matter, proceeding from certain criteria (the field of activity, the sphere of public relationships, the problem of scientific research, etc).

Consolidation lies in the fact that a number of normative acts concerning the same problem or a few interconnected problems, are joined into one enlarged general act, which is a full substitution of all normative acts that became its 
components. The same as in case of incorporation, consolidation does not change the contents of its sources, but just changes their form.

And last, - codification is the form of systematization of normative acts having a common object of regulation, which presupposes not only bringing together a few law sources into one normative act (code, regulations, status), but essential contents changes - elimination of variant readings, inconsistency, obsolete norms, etc. This is 'the way of putting legislation in good order, ensuring its systematic character and coordination, or a form of systematization in which the design of the act under consideration includes both available and new forms, that bring about changes in regulation of a certain sphere of public relations' (Andreitsev, 2008, p.22). 'Codification is meant to critically reconsider the norms available, to do away with contradictions and discrepancy between them, to eliminate repetitions, obsolete clauses, gaps, duplicating norms' (Chepus, 2010, p.35).

As a form of legislation systematization, resulting in adoption of a codifying normative legal acts, new both in its form and content (code, fundamentals, regulations, statute, rules), 'codification is a special kind of norm creation, as it combines direct lawmaking (passing or abolishing a codifying law, code, Fundamentals of legislation, regulations of the Supreme Council of Ukraine) and subordinate lawmaking (while working out statutes, regulations, rules, instructions - that is legal documents belonging to the competence of the executive power). That is why codification is realized by persons authorized by organs of state government in the processes of both direct and subordinate lawmaking' (Hetman, E. 2008, p.288).

Two most important conditions that determine the possibility and expediency of codification are as follows:

- the legislation readiness for the codification, a certain extent of its fragmentation. It means that acts that are to be codified must make a well-formed group with characteristics that are necessary for the object of codification (Shebanov, 1971);

- the legislation that is united in the codification act must be based on the same principles and characterized by a certain unity of its sources, by a community of its fundamental principles. And this can only be observed in case the legislator selects a certain branch of lawmaking or a certain section, proceeding from objective reasons - economic and political necessities for a complex legal regulation of a given group of public relationships (ibid).

What are the characteristics of codification acts?

Their content peculiarities are as follows (Rogach, 2001; Chukhvichev, 2009):

- they bring about serious changes to regulation of public relationships on the basis of making a new, or changing or putting the finishing touches to the current legislation; the new normative legal act abolishes all the body of acts that were systemized;

- are to thoroughly solve all the main problems of legal regulation of a certain sphere of public relations;

- have a generalized character - summerize all the normative requirements within a certain legislation structure (sphere, part of a sphere, an institute, etc);

- are characterized by a logical completion, systemic interconnection of elements.

Besides content peculiarities codification acts form has also some specific features (Rogach, 2001):

- the title names the type of the act (code, statute, thesis, etc);

- a specific structure and a clear division of functional roles $\mathrm{f}$ its different parts: a general and a specific one;

- a lengthy period of time of its being in force;

- its confirmation by a corresponding act (law, order, regulation).

Proceeding from such criteria as practical application, as well as necessary initial conditions of the usage give grounds for the conclusion that nowadays under the conditions of Ukraine the most promising form of systematizing environmental legislation must be its codification, that is working out and introduction of the Environmental Code of Ukraine, its main goals being as follows:

- to make a general 'inventory' of environmental legislation;

- to bring the norms of the legislation into line with the Constitution of Ukraine;

- systematize and put in order the legal norms;

- to bring the legal technology into line with the requirements that are to ensure the fullness of the norms logical structure (the content, the conditions of application, the addressee, the character, enumeration of sanctions, the 
guarantor), to make norms technological and convenient for the usage by the addressees (minimum of reference notes, clearness, transparency, simplicity, etc);

- to remove all contradictions that exist between norms, to take away those that are in conflict with one another or duplicate one another;

- to fill up the gaps in the environmental legislation;

- finally: proceeding from the abovementioned tasks, make the formal state environmental institutions active and high quality legal norms of regulating social relationships in the field of environmental protection and ensurance of the society environmental safety.

\section{Discussion}

Ukraine transition to the Green Economy stipulates the necessity of quite a lot of systemic transformations of all aspects of society life: from introducing technological innovations to manufacturing most important products and providing services, to working out concrete financial mechanisms of stimulating environmental and resource saving activity of all members of society.

Nowadays the necessity of these transformations in Ukraine is mainly proclaimed, but very little is really done.

One of the main reasons is the fact that the current system of economic institutions concerning environmental protection dose not solve the two main problems: on the one hand, - to stimulate environmental activity, on the other hand, - to prevent and block any activity damaging to environment.

A radical improvement of environmental legislation is necessary to remote this reason.

The most effective and promising way of introducing these changes in Ukraine is the codification of the environmental law norms and passing the Environmental Code of Ukraine, its main task will be to create, on the basis of available legal institutions, of an integral mechanism of legal regulation of environmental relationships, to ensure systematization and setting to rights the legal norms, to reduce the number of normative acts in the sphere of environmental activity, to do away with contradictions and duplication in the environmental legislation; and thus effectively improve the activity and quality of institutions regulating social relationships in the field of environmental protection and ensuring the environmental safety of society.

The main result of introducing the Environmental Code of Ukraine must be general improvement of the quality and effectiveness of environmental protection on the basis of bringing legislation into line with real requirements of the society development and improvement of state management and financing environmental activity.

The effectiveness of the legislation will essentially rise, first of all, due to the fact, that meeting its requirements will become simpler and less costly for the addressees, that is necessary conditions will be created for all members of society to observe the norms of the environmental legislation as it will become sensible and advantageous.

Besides, the Environmental Code of Ukraine introduction will create conditions under which it will be impossible for officials to abuse their authority by way of taking advantage of contradictions in the legislation (for instance, selective usage in a concrete situation of one or another from a group of norms to 'motivate the rightfulness' of demanding a bribe from the 'offender'. Such actions, even if ill not become absolutely impossible, at any rate will be essentially restricted. So the quality and effectiveness of the legislation will grow.

\section{References}

Andreitsev, V. (2008). Axiological aspects of codification of legislation. Visnyk akademii pravovyh nauk Ukrayiny,4, 22-36 (In Ukrainian).

Babenko, V., Nakisko, O., Latynin, M., Rudenko, S., Lomovskykh, L., \& Girzheva, O. (2019). Procedure of Identifying of the Parameters of the Model of Management of Technological Innovations in Economic Systems. 2019 IEEE International Scientific-Practical Conference Problems of Infocommunications, Science and Technology (PIC S\&T), Kyiv, Ukraine, 324-328. https://doi.org/10.1109/PICST47496.2019.9061259

Babenko, V., Perevozova, I., Kravchenko, M., Krutko, M., \& Babenko, D. (2020). Modern processes of regional economic integration of Ukraine in the context of sustainable development. E3S Web Conf., 166(2020), 12001. https://doi.org/10.1051/e3sconf/202016612001

Bikadorov, V. (2008). The theory of state and law. Kharkiv (In Ukrainian).

Chepus, A. (2010). Codification of legislation as one of the trends of Russian state legal policy. Pravovaya politika $i$ pravovaya zhizn, 1, 34-37 (In Russian). 
Chukhvichev, D. (2009). Codification acts, their specifics and meaning in the legal system. Gosudarstvo i pravo, 8 , 5-13 (In Russian).

Hetman, A. (2014). The conception of developing environmental law and legislation as a precondition of ensuring a national environmental policy. Ezhegodnik ukrainskogo prava, 6, 465-474 (In Russian).

Hetman, E. (2008). Codification as a special kind of lawmaking. Visnyk akademii pravovyh nauk Ukrayiny, 3, 283-288 (In Ukrainian).

Koniaieva, Y., Dzoba, O., Hostryk, A., Lisova, O., \& Babenko, D. (2020). Non-conventional renewable energy: comparative analysis of the prospects for the development of energy-economic complex of a state. SHS Web of Conf., 2019, 65. https://doi.org/10.1051/shsconf/20196504020

Legislation of $\quad$ Ukraine. (2019). Retrieved $\quad$ May 9, 2019, $\quad$ from http://zakon.rada.gov.ua/cgi-bin/laws/main.cgi?user=index

Meadows, D. et al.. (1972). The Limits to Growth. Signet, N.Y.

Rogach, O. (2001). Codification acts in the legal system of Ukraine: notions, characteristics, properties. Visnyk akademii pravovyh nauk Ukrayiny, 4, 231-236 (In Ukrainian).

Ryabetz, K. (2009). Environmental law of Ukraine. Kyiv (In Ukrainian).

Shebanov, A. (1971). The system of legislation as a scientific foundation of codification. Sovetckoe gosudarstvo $i$ pravo, 12, 30-38 (In Russian).

The European Union. (2014). Association agreement between the European Union and its Member States, of the one part, and Ukraine, of the other part, Brussels. Official Journal of the European Union, 29(5), 161-2137.

UNDESA. (2012). A guidebook to the Green Economy Issue 3: exploring green economy policies and international experience with national strategies Division for Sustainable Development [online]. Retrieved May 9, 2019, from https://sustainabledevelopment.un.org/content/documents/738GE\%20Publication.pdf

Vasylieva, N. (2019). Problems and Prospects of Food Security in Ukraine. Bulgarian Journal of Agricultural Science, 25(4), 668-676. Retrieved from https://www.agrojournal.org/25/04-08.pdf

Zanizdra, M. (2018). Conceptual principles of 'green smart" industry. Ekonomika promislovosti, 1, $61-85$ (In Ukrainian).

\section{Copyrights}

Copyright for this article is retained by the author(s), with first publication rights granted to the journal.

This is an open-access article distributed under the terms and conditions of the Creative Commons Attribution license (http://creativecommons.org/licenses/by/4.0/). 